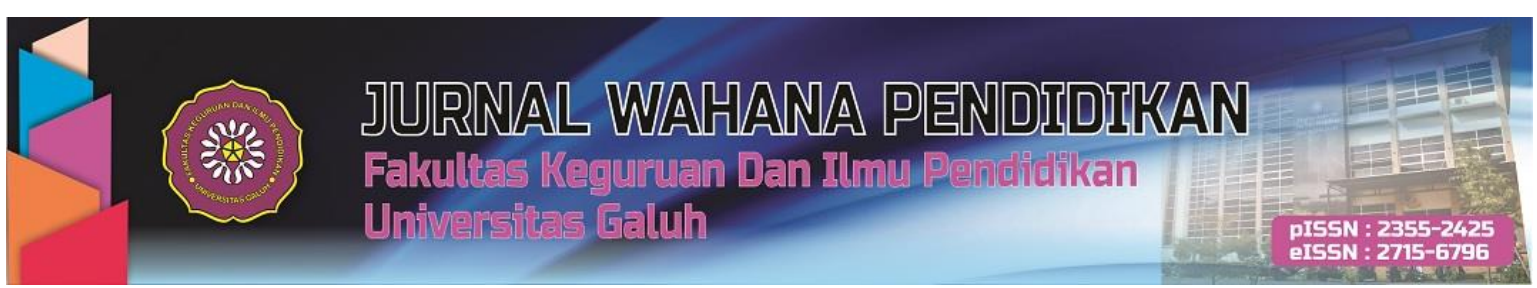

https://jurnal.unigal.ac.id/index.php/jwp

\title{
SNOWBALL THROWING BERBANTU MEDIA TEKA-TEKI SILANG PADA MATA PELAJARAN EKONOMI
}

\author{
Tati Heryati ${ }^{1}$ \\ 1 Universitas Galuh, Jl. R. E. Martadinata No.150, Ciamis, Jawa Barat, Indonesia \\ Email: tati.cimari@gmail.com
}

\section{ABSTRACT}

The low learning outcomes is a very crucial problem in learning, because learning it is the benchmarks of success in achieving learning objectives. Low learning outcomes are motivated by various factors including the selection of learning models with the right type to be used by educators. The purposes of this study are to find out the differences: 1) learning outcomes who apply the Snowball Throwing assisted by the crossword puzzle media on initial measurements (pretest) and posttest; 2) learning outcomes of students who apply the lecture method on pretest and posttest; and 3) improvement of learning outcomes students who apply the Snowball Throwing cooperative learning by crossword media with who apply the lecture method at the final measurement (posttest). The research method used is the Quasi Experimental and data analysis using the t test. The conclusion of this study is learning outcomes of students who apply Snowball Throwing type assisted by crossword puzzles are higher than who apply the lecture method.

keywords: crosswords, learning outcomes, snowball throwing.

\begin{abstract}
ABSTRAK
Rendahnya hasil belajar merupakan permasalahan yang sangat krusial dalam pembelajaran, karena hal tersebut merupakan indikator keberhasilan kegiatan pembelajaran. Rendahnya hasil belajar dapat dipacu oleh berbagai faktor salah satunya penggunaan model pembelajaran. Penelitian ini bertujuan mngidentifikasi perbedaan: 1) Hasil belajar siswa dengan menggunakan metode Snowball Throwing berbantu media teka teki silang pada saat pretest dan posttest; 2) Hasil belajar siswa yang menerapkan metode ceramah pada saat pretest dan posttest; dan 3) Peningkatan hasil belajar siswa yang menerapkan cooperative learning tipe Snowball Throwing berbantu media teka teki silang dengan yang menerapkan metode ceramah pada saat posttest. Penelitian menggunakan metode eksperimen dan analisis data menggunakan Uji t. Hasil penelitian menunjukkan bahwa hasil belajar siswa dengan cooperative learning tipe Snowball Throwing berbantu media teka-teki silang lebih tinggi dibanding dengan yang menggunakan metode ceramah.
\end{abstract}

Kata Kunci: hasil belajar, snowball throwing, Teka-Teki Silang

Cara sitasi: Heryati, T. (2021). Snowball Throwing Berbantu Media Teka-Teki Silang Pada Mata Pelajaran Ekonomi. Jurnal Wahana Pendidikan, 8(1), 85- 90. 


\section{PENDAHULUAN}

Hasil belajar mengindikasikan keberhasilan dalam pencapain tujuan pembelajaran, Hasil belajar menggambarkan berbagai kemampuan yang diperoleh siswa setelah mengikuti pembelajaran. Tujuan pembelajaran di Sekolah yaitu "Meletakan dasar kecerdasan, pengetahuan, kepribadian, akhlak mulia, serta keterampilan untuk hidup mandiri dan mengikuti pendidikan lebih lanjut (Rumiati, 2020: 212). Sebagaimana pendapat Sudjana (2017: 22) yang menjelaskan bahwa hasil belajar merupakan kemampuan-kemampuan yang dimiliki peserta didik setelah menerima pengalaman belajar. Tinggi rendahnya hasil belajar diukur dengan berberpedoman pada Kriteria Ketuntasan Minimal yang menjadi standar penilaian di sekolah. Kriteria Ketuntasan Minimal merupakan upaya sekolah untuk mengukur ketuntasan hasil belajar dengan besaran angka yang ditentukan sesuai harapan sekolah yang didasarkan pada estimasi kemampuan peserta didik dalam mencapai standar yang ditentukan. Sebagaimana tercantum dalam Peraturan Menteri Pendidikan dan Kebudayaan Republik Indonesia Nomor 23 Tahun 2016 tentang Standar Penilaian Pendidikan yang dinyatakan bahwa Kriteria Ketuntasan Minimal ditentukan oleh satuan pendidikan dengan mengacu pada standar kompetensi kelulusan dan dengan mempertimbangkan karakteristik peserta didik, mata pelajaran dan kondisi satuan pendidikan.

Hasil observasi awal menunjukkan bahwa permasalahan yang terjadi SMA Negeri 1 Taraju yaitu belum optimalnya perolehan hasil belajar. rata-rata nilai ulangan harian mata pelajaran ekonomi mayoritas belum mencapai nilai KKM. Kaitannya dengan metode mengajar, masih banyak pendidik yang memilih metode pembelajaran yang konvensional. Pendidik menjelaskan materi dan peserta didik menyimak materi, sehingga keterlibatan peserta didik dalam pembelajaran dikelas sangat terbatas dan mengakibatkan hasil belajar peserta didik rendah.

Penulis berasumsi bahwa harus dicari metode yang paling efektf untuk meningkatkan keterlibatan peserta didik sebagai upaya untuk meningkatkan hasil belajar. Salah satu model yang dapat digunakan yaitu Cooperative Learning. Sebagaimana menurut Slavin dalam Rusman (2014) dijelaskan bahwa pembelajaran kooperatif menggalakan siswa untuk berinteraksi secara aktif dan positif di dalam kelompok. Salah satu metode yang akan digunakan oleh penulis yaitu tipe Snowball Throwing. Menurut Miftahul Huda (2014) dijelaskan bahwa tipe Snowball Throwing adalah metode yang melatih peserta didik untuk lebih tanggap menerima pesan dari orang lain dan menyampaikan pesan tersebut kepada teman satu kelompoknya". Penggunaan model pembelajaran Snowball Throwing dapat menigkatkan aktivitas dan kreatifitas siswa, melatih siswa belajar mandiri dalam pengetahuan berdasarkan diskusi (Rosidah, 2017: 31). Berdasarkan penjelasan tersebut, maka penggunaan metode Snowball Throwing berpotensi meningkatkan hasil belajar peserta didik.

Penelitian ini bertujuan untuk mengetahui: 1) hasil belajar yang menggunakan metode Snowball Throwing berbantu teka teki silang pada pretest dan posttest; 2) hasil belajar yang menerapkan metode ceramah pada pretest dan posttest; 3) Perbedaan hasil belajar yang menerapkan tipe Snowball Throwing berbantu media teka teki silang dengan yang menerapkan metode ceramah pada saat posttest.

\section{METODE PENELITIAN}

Penelitian ini menggunakan metode eksperimen. Desain yang digunakan yaitu Quasi Eksperimental Nonequivalent Control Group Design. Populasi terdiri dari seluruh peserta didik kelas XI IPS di SMAN 1 Taraju sejumlah 154 orang dengan menggunakan Sampling Purposive. Terpilih kelas XI IPS 2 sebagai kelas eksperimen dan XI IPS 3 sebagai kelas kontrol.

\section{HASIL DAN PEMBAHASAN \\ Perbedan Hasil Belajar Menggunakan Metode Snowball Throwing Berbantu Media Teka-Teki Silang}

Hasil belajar peserta didik menggunakan metode Snowball Throwing dari pretest ke posttest menunjukkan perbedaan signifikan dengan dibuktikan rerata pretest 49,38 dan posttest 91,04 dan N- 
Gain 0,82 yang kategori tinggi. Ini berarti metode Snowball Throwing efektif diterapkan untuk mata pelajaran ekonomi.

Penerapan metode Snowball Throwing membuat peserta didik menjadi aktif karena mereka lebih berperan selama proses pembelajaran. Siswa dibentuk kelompok belajar dibagi rata tanpa membedakan status, ras, suku dan agama sehingga dapat mengurangi kesenjangaan diantara peserta didik sehingga model pembelajaran ini menciptakan suasana belajar yang membuat siswa mudah memahami materi. Peserta didik semakin tanggap dalam menerima pesan karena memiliki tanggung jawab terhadap tim sehingga menimbulkan semangat dalam proses pembelajaran. sejalan dengan Huda (2014) yang menyatakan bahwa metode Snowball Throwing merupakan strategi melatih peserta didik supaya lebih responsif menerima pesan dari orang lain dan menyampaikan pesan tersebut kepada teman satu kelompoknya.

Metode Snowball Throwing dikombinasikan dengan penggunaan media berupa teka-teki silang. Media teka-teki silang berhasil meningkatkan fungsi kerja otak dan mengasah kemampuan berpikir cepat dan mengembangkan kemampuan berpikir dengan cara membuat soal dan mengisi teka-teki silang. Menurut Hidayati (dalam Nugroho, 2017) melakukan pengisian teka-teki silang tidak hanya sebagai hiburan mengisi waktu luang, namun dapat meningkatkan fungsi kerja otak sehinga berpotensi mencegah kepikunan dini. Selain itu juga berguna menambah wawasan pengetahuan serta mengasah kemampuan berpikir cepat. Selain itu Snowball Throwing juga membangkitkan motivasi untuk mengikuti pembelajaran karena pendidik memberikan reward kepada kelompok terbaik dalam pengisian dari teka-teki silang dan soal essai yang dibuat oleh kelompok yang lain. Peningkatan motivasi dan antusiasme tersebut akhirnya meningkatkan perolehan nilai tes akhir.

\section{Perbedaan Hasil Belajar yang Menerapkan Metode Konvensional}

Penelitian menunjukan bahwa terdapat perbedaan hasil belajar yang menerapkan metode konvensional di kelas kontrol dengan dibuktikan perolehan rerata pretest 49,80; rerata posttest 78,82; diperkuat dengan perolehan N-Gain 0,58 termasuk kategori sedang. Hal tersebut menunjukkan metode ceramah kurang layak diterapkan pada mata pelajaran ekonomi karena belum mencapai peningkatan pada taraf kategori tinggi.

Kurang maksimalnya peningkatan nilai tes terjadi karena peserta didik kurang antusias. Interaksi cenderung dominan satu arah sehingga peserta didik menjadi pasif dan jenuh. Metode ceramah kurang melibatkan peserta didik sehingga banyak yang tidak memperhatikan, tertidur dan merasa bosan sehingga membuat konsentrasi terganggu. Djamarah dan Zain (2010) mengemukakan kelemahan metode ceramah diataranya berpotensi menciptakan verbalisme karena materi hanya dihafal. Selain itu metode ini juga merugikan siswa yang berkarakter visual karena materi diterima hanya melaui indera pendengaran tanpa melihat objek visualnya. Selain itu tentu saja berpotensi menimbulkan kebosanan dan cenderung membuat peserta didik pasif.

Penggunaan metode ceramah dalam pembelajaran akan membuat peserta didik menjadi pasif jika terus dilakukan secara berulang-ulang dan pola interaksi hanya dilakukan satu arah. Namun jika metode ceramah yang diterapkan melibatkan peserta didik secara fisik dan psikis dapat meningkatkan kadar keaktifan peserta didik. Pendidik dapat lebih interaktif ketika proses pembelajaran berlangsung agar materi yang disampaikan dapat menyentuh emosi dari peserta didik yaitu dengan menyisipkan sebuah cerita, humor, dan lain sebagainya. Hal tesebut dapat dilakukan pendidik sebagai upaya agar metode ceramah tidak membosankan dan dapat meningkatkan hasil belajar.

\section{Perbedaan Hasil Belajar Menggunakan Metode Snowball Throwing Berbantu Media Teka-Teki Silang dengan yang Menerapkan Metode Ceramah}

Peningkatan hasil belajar yang menerapkan model kooperatif tipe Snowball Throwing berbantu media teka-teki silang berbeda signifikan dengan yang menerapkan metode ceramah pada pengukuran akhir (posttest). Diperkuat rerata N-Gain, kelas eksperimen 0,82 kategori tinggi, dan N- 
Gain kelas kontrol 0,58 kategori sedang. Dengan demikian metode Snowball Throwing lebih efektif digunakan untuk mata pelajaran ekonomi dalam kompetensi dasar Kerja Sama Ekonomi Internasional dibandingkan dengan metode ceramah.

Model kooperatif dengan metode Snowball Throwing berbantu teka-teki silang membawa peserta didik menjadi aktif dan memiliki tanggung jawab terhadap kelompok untuk dapat membuat soal dan mengerjakan soal dari kelompok lain selama proses pembelajaran serta bersaing untuk mendapatkan nilai terbesar. Siswa lebih antusias karena dituntut cepat tanggap menerima dan menyampaikan pesan kepada peserta didik yang lain. Dengan adanya modifikasi menggunakan media teka-teki silang yang dibuat oleh peserta didik dalam kelompok masing-masing, berhasil membangkitkan semangat peserta didik dalam proses pembelajaran. Siswa berhasil lebih teliti selama pengerjaan dan melatih ketajaman otak dari peserta didik. Sehingga informasi lebih mudah diterima dan mudah dipahami. Sebagaimana Mukrimaa (2014) menjelaskan kelebihan teka-teki silag yaitu dapat meningkatkan ketelitian dan kejelian siswa dalam mengasah otak.

Peningkatan hasil belajar menggunakan metode Snowball Throwing berbeda dengan peserta didik yang menerapkan metode ceramah. Melalui penerapan metode ceramah peningkatannya kurang optimal karena metode ceramah dominan teacher centered dan siswa pasif. Sejalan dengan pendapat Wijaya (2016) bahwa di dalam penggunaan metode ceramah lebih didominasi oleh pendidik yang aktif menjelaskanvdan peserta didik pasif sehingga mereka mudah menjadi jenuh. Pembelajaran sangat ketergantungan kepada guru dan siswa kurang bisa mandiri dalam mencari materi pembelajaran.

Penerapan metode Snowball Throwing berbantu media teka-teki silang dan penerapan metode ceramah berpengaruh terhadap peningkatan nilai posttest. Namun demikian peningkatan yang menerapkan model kooperatif tipe Snowball Throwing berbantu media teka-teki silang lebih signifikan daripada peningkatan yang menerapkan metode ceramah pada mata pelajaran ekonomi.

\section{KESIMPULAN}

Berdasarkan hasil penelitian, diketahui bahwa:

1. Hasil belajar yang menerapkan metode Snowball Throwing berbantu media teka teki silang mengalami peninngkatan pretest ke posttest.

2. Terdapat perbedaan hasil belajar yang menerapkan metode konvensional pada saat posttest.

3. Hasil belajar yang menerapkan mtode Snowball Throwing berbantu media teka teki silang berbeda signifikan dengan yang menerapkan ceramah.

\section{REKOMENDASI}

berikut:

Berdasarkan penelitian yang penulis telah lakukan maka penulis memberi saran sebagai

1. Penggunakan Snowball Throwing sebaiknya dikombinasikan dengan inovasi media pembelajaran yang lebih menarik.

2. Penerapan Snowball Throwing sebaiknya dikombinasikan dengan metode dan media selain tekateki silang.

\section{UCAPAN TERIMAKASIH}

Penulis sampaikan terima kasih pada pihak SMAN 1 Taraju karena telah memperkenankan untuk melakukan penelitian eksperimen.

\section{DAFTAR PUSTAKA}

Djamarah, Syaiful Bahri dan Aswan Zain. (2010). Strategi Belajar Mengajar. Jakarta: Rineka Cipta.

Huda, Miftahul. (2014). Model-Model Pengajaran dan Pembelajaran. Yogyakarta : Pustaka Pelajar. 
Rusman. (2014). Model-Model Pembelajaran Mengembangkan Profesionalisme Guru. Jakarta : PT.RajaGrafindo Persada

Sudjana, Nana. (2017). Penilaian Hasil Proses Belajar Mengajar. Bandung : PT. Remaja Rosdakarya.

Sugiyono. (2016). Metode Penelitian Pendidikan : Pendekatan Kuantitatif, Kualitatif dan RRD. Bandung: Alfabeta.

Mukrimaa, Syifa S. 2014. 53 Metode Belajar dan Pembelajaran Plus Aplikasinya. Pendidikan Manajemen Bisnis. Universitas Pendidikan Indonesia. Bandung. Tersedia pada: https://www.slideshare.net/SyifaMukrimaa/53-metode-pembelajaran-ebook. Diakses pada tanggal 1 Desember 2019.

Nugroho, Wildan Abdi. 2017. Upaya Meningkatkan Motivasi Dan Prestasi Belajar IPS Melalui Strategi Snowball Throwing Berbantu Media Teka-Teki Silang (Tts) Siswa Kelas IV Sd Negeri 02 Karanggude. Fakultas Keguruan dan Ilmu Pendidikan. Universitas Muhamadiyah Purwokerto. Purwokerto. Tersedia pada: http://repository.ump.ac.id/3919/. Diakses pada tanggal 16 November 2019.

Rosidah, Ani. 2017. Penerapan Model Pembelajaran Kooperatif Snowball Throwing untuk Meningkatkan Hasil Belajar Siswa pada Pembelajaran IPS. Jurnal Cakrawala Pendas Volume 3 Nomor 2 Edisi Juli 2017.

Rumiati, Eti. 2020. Penggunaan Metode Resitasi untuk Meningkatkan Hasil Belajar Siswa pada Pembelajaran IPS Terpadu tentang Letak Geografis dan Koordinat Negara Asean (Penelitian Tindakan Kelas di Kelas VIII-G SMPN 6 Tasikmalaya). Jurnal Wahana Pendidikan Volume 7 Nomor 2.

Wijaya, Devilia Sistantri. 2016. Penerapan Model Student Teams Achievement (STAD) dan Metode Ceramah Terhadap Peningkatan Prestasi Belajar IPS pada Siswa Kelas V SD Negeri 1 Rajabasa Raya Bandar Lampung. Fakultas Keguruan dan IImu Pendidikan. Universitas Lampung. Bandar Lampung. Tersedia pada: http://digilib.unila.ac.id/24230/19. Diakses pada tanggal 08 April 2020. 